\title{
Paleoglaciation of the Tibetan Plateau and surrounding mountains based on exposure ages and ELA depression estimates
}

Jakob Heyman

Department of Physical Geography and Quaternary Geology

Stockholm University

10691 Stockholm, Sweden

jakob.heyman@natgeo.su.se

\begin{abstract}
The Tibetan Plateau holds an ample record of past glaciations, and there is an extensive set of glacial deposits dated by exposure dating. Here a compilation is presented of ${ }^{10} \mathrm{Be}$ exposure ages from 485 glacial deposits with 1855 individual samples on the Tibetan Plateau, and ELA depression estimates for the glacial deposits based on a simple toe to headwall ratio approach. To recalculate the Tibetan Plateau exposure ages, ${ }^{10} \mathrm{Be}$ production rates from 24 calibration sites across the world are compiled and recalibrated yielding an updated global reference ${ }^{10} \mathrm{Be}$ production rate. The recalculated exposure ages from the Tibetan Plateau glacial deposits are then divided into three groups based on exposure age clustering, to discriminate good (well-clustered) from poor (scattered) deglaciation ages. A major part of the glacial deposits have exposure ages affected by prior or incomplete exposure, complicating exposure age interpretations. The well-clustered deglaciation ages are primarily from mountain ranges along the margins of the Tibetan Plateau with a main peak between 10 and $30 \mathrm{ka}$, indicating glacial advances during the global LGM. A large number of deglaciation ages older than 30 ka indicates maximum glaciation predating the LGM, but the exposure age scatter generally prohibits accurate definition of the glacial chronology. The ELA depression estimates scatter significantly, but the main part is remarkably low. Average ELA depressions of $337 \pm 197 \mathrm{~m}$ for the LGM and $494 \pm 280 \mathrm{~m}$ for the pre-LGM indicate restricted glacier expansion.
\end{abstract}

Keywords: Tibetan Plateau, glaciation, exposure dating, ELA depression, ${ }^{10} \mathrm{Be}$ production rate

\section{Introduction}

The glacial history of the Tibetan Plateau and the surrounding mountains has attracted significant interest, with a large body of research investigating the extent, timing, and climatic implications of past glaciations. The Tibetan region mountain ranges hold a large part of contemporary glaciers outside the polar regions, and these glaciers provide meltwater for several of the largest Asian rivers. With a projected future warming (Christensen et al., 2007) possibly having a significant impact on contemporary 
glaciers, the glacier history of the Tibetan Plateau might yield important insights on glacier response to climate change.

The extent of past glaciers in the Tibetan region has been a topic of debate, with reconstructions ranging from limited alpine style glaciations (e.g. Li et al., 1991) to a large ice sheet covering the entire plateau (Kuhle, 2004). The advent of cosmogenic exposure dating has enabled constraining and defining the timing of past glaciations, and this chronological tool has been frequently applied to mountain regions of the Tibetan Plateau. Cosmogenic exposure dating of deposits formed by restricted glaciers in the Tibetan region mountains has, with exposure ages ranging up to more than half a million year, disproved the Tibetan ice sheet hypothesis for at least the last few glacial cycles (cf. Owen et al., 2008; Owen and Dortch, 2014). Further, exposure dating and the inferred timing of past glaciations have been used to investigate regional variations of glacial chronologies and the paleoclimate (e.g., Owen et al., 2005; Scherler et al., 2010; Zech, 2012; Amidon et al., 2013; Dortch et al., 2013).

To infer climate change based on glacier change, a common approach is to reconstruct the equilibrium line altitude (ELA) for recorded past and present extents of a glacier and calculate the ELA depression $(\triangle E L A)$ for past glaciations. The ELA is the altitude at a glacier surface where accumulation equals ablation and it is closely related to local climate. Several techniques exist for reconstructing the ELA of past and present mountain glaciers in the absence of mass balance data, and the various methods have been presented in comprehensive reviews (Meierding, 1982; Benn and Lehmkuhl, 2000; Porter, 2001; Benn et al., 2005). Multiple studies have presented $\triangle E L A$ estimates for individual glaciers and regions of the Tibetan Plateau region, but only limited attempts have been made to estimate the $\triangle E L A$ on a plateau-wide scale. Owen and Benn (2005) presented a compilation of $\triangle E L A$ estimates for 21 locations of the Tibetan Plateau region, and Mark et al. (2005) included $48 \Delta E L A$ estimates from the Tibetan Plateau region in a worldwide compilation. However, as pointed out by Owen and Benn (2005) the variety of methods for reconstructing the $\triangle E L A$ and, in particular, the chronological uncertainties for many past glaciations, have prevented comprehensive and accurate $\triangle E L A$ estimates for the Tibetan Plateau region.

Here a compilation of glacial deposit ${ }^{10} \mathrm{Be}$ exposure ages and associated $\triangle$ ELA estimates from across the Tibetan Plateau region is presented. The extensive dataset enables a plateau-wide view of past glacial advances ( $\triangle E L A$ ) with improved temporal constraints (exposure ages). To recalculate the exposure ages an updated global ${ }^{10} \mathrm{Be}$ reference production rate is used based on recalibration of data from $24{ }^{10} \mathrm{Be}$ production rate calibration sites.

\section{Study area}

The Tibetan Plateau region comprises an area of $3 \times 10^{6} \mathrm{~km}^{2}$ higher than $3000 \mathrm{~m}$ a.s.l. that has formed as a result of the India Asia collision (Harrison et al., 1992). It is characterized by a low-relief plateau surface surrounded by and broken by higher mountain ranges (Fig. 1). Present-day glaciers cover c. $1.2 \times 10^{5} \mathrm{~km}^{2}$ with most glaciers in the Himalaya and Karakoram range (Arendt et al., 2012). Past glacial advances have occurred in high-relief alpine environments with extensive present-day glaciers (e.g. Seong et al., 2007; Owen et al., 2009) as well as in currently non-glaciated low-relief mountain regions (e.g. Heyman et al., 2009; Fu et al., 2013a). Exposure dating has been applied across the plateau with most studies focusing on the mountain regions along the plateau margin. Here, the exposure age sites have been divided into 


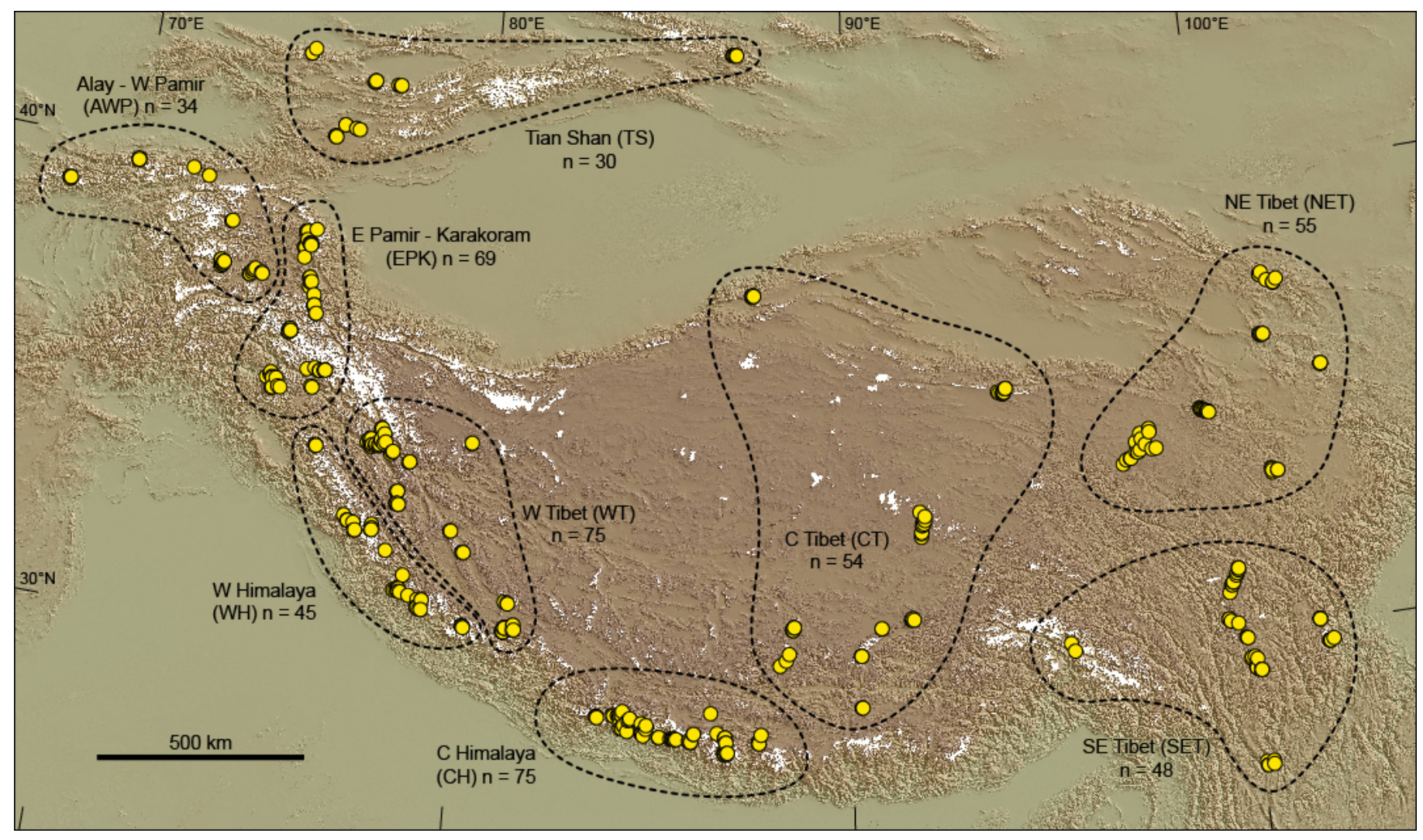

Fig. 1. Map of the Tibetan Plateau and surrounding mountains with glacial deposit locations and the nine regions they have been divided into. The glaciers (white) are based on Arendt et al. (2012) with minor updates.

nine regions: Tian Shan, Alay - W Pamir, E Pamir - Karakoram, W Tibet, W Himalaya, C Himalaya, C Tibet, NE Tibet, and SE Tibet (Fig. 1).

\section{Methods}

\subsection{An updated global ${ }^{10}$ Be reference production rate}

To calculate exposure ages based on ${ }^{10} \mathrm{Be}$ concentration, location, and sample information, the CRONUS online calculator code (Balco et al., 2008; http://hess.ess.washington.edu/) was used with an updated reference spallation ${ }^{10} \mathrm{Be}$ production rate. Several recent ${ }^{10} \mathrm{Be}$ production rate calibration studies have indicated that the reference ${ }^{10} \mathrm{Be}$ production rate used in the CRONUS online calculator is a bit too high (Balco et al., 2009; Putnam et al., 2010; Fenton et al., 2011; Kaplan et al., 2011; Briner et al., 2012; Goehring et al., 2012; Ballantyne and Stone, 2012; Young et al., 2013; Kelly et al., in press). To calculate an updated production rate the reference ${ }^{10} \mathrm{Be}$ production rate of the CRONUS online calibration sites (Nishiizumi et al., 1989; Gosse et al., 1995; Larsen, 1996; Stone et al., 1998; Kubik and Ivy-Ochs, 2004; Farber et al., 2005) as well sites in recent calibration studies have been recalibrated (Fig. 2). In total, 161 samples from 24 sites with a minimum of three samples each are included in the calibration dataset. Sample data for latitude, longitude, elevation/air pressure, sample thickness and density, topographic shielding, erosion, and ${ }^{10} \mathrm{Be}$ concentration is taken from the original publications. Error-weighted mean ${ }^{10} \mathrm{Be}$ concentrations are used for samples with repeat measurements. The ${ }^{10} \mathrm{Be}$ standardization used for the measurements is taken from the original publication, or based on the laboratory for calibration studies predating Nishiizumi et al. (2007). All calibration ages have been adjusted to the sampling year 

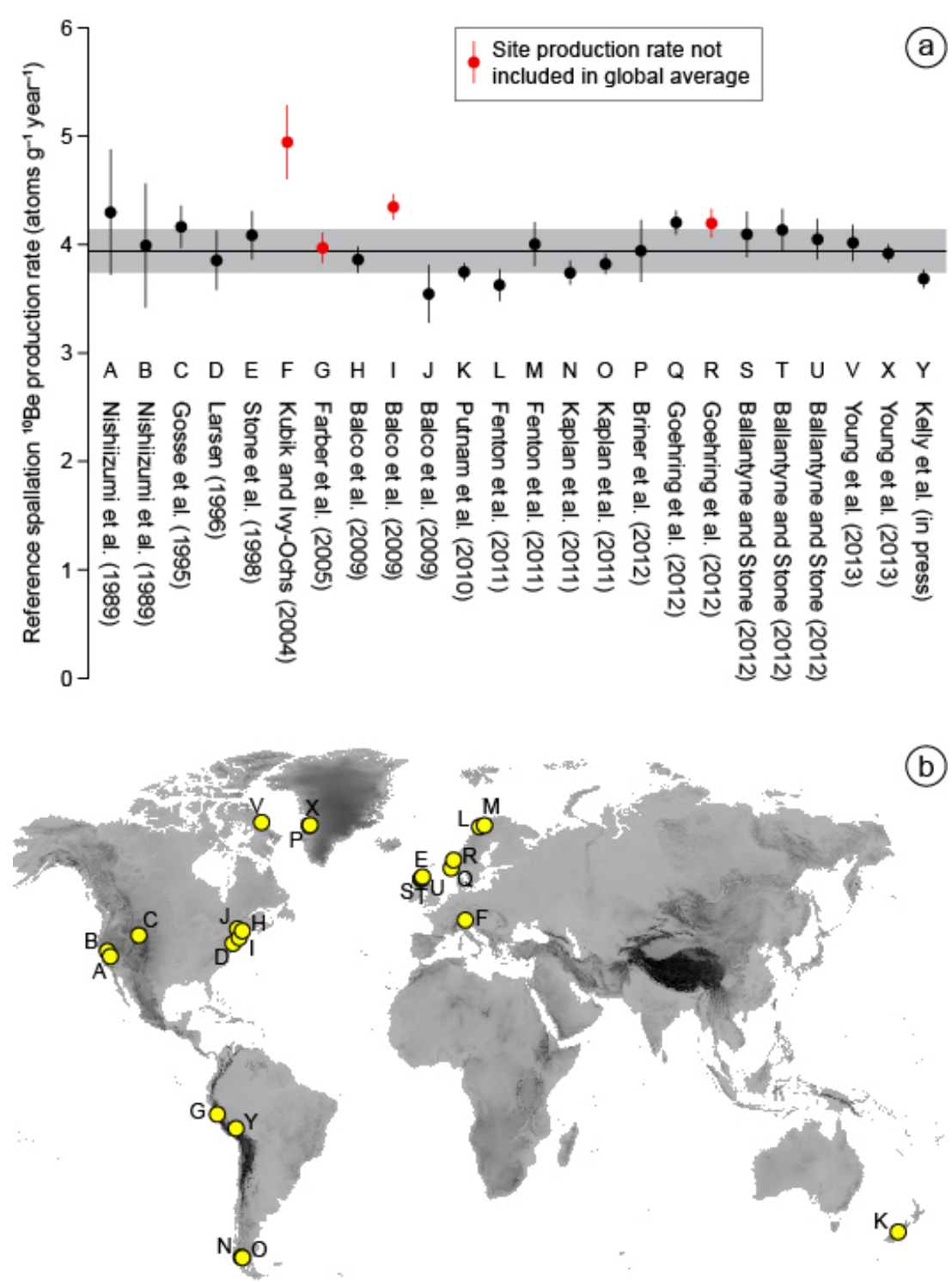

Fig. 2. (a) Reference spallation ${ }^{10}$ Be production rate using the CRONUS Lm (Balco et al., 2008) scaling scheme for 24 sites used for production rate calibration. The production rates of sites $G, I, R$ are excluded because of too much scatter $\left(\chi_{R}^{2}>2\right.$ due to prior and/or incomplete exposure) and the shown production rates of those sites are based on all samples. The production rate of site $\mathrm{F}$ is excluded as an outlier because of the significantly higher reference production rate than all other sites. The horizontal black line and grey band show the arithmetic mean and standard deviation of the remaining 20 site production rates $\left(3.94 \pm 0.20\right.$ atoms $\mathrm{g}^{-1}$ year ${ }^{-1}$ ), which is used as the reference production rate to calculate the Tibetan Plateau exposure ages. See Supplementary dataset for full data. (b) Map showing the location of the production rate calibration sites.

and radiocarbon ages have been recalibrated using the IntCal13, Marine13, and SHCal13 curves (Reimer et al., 2013; Hogg et al., 2013) using OxCal 4.2 (Bronk Ramsey, 2009). The calibration age for the Sierra Nevada sites (Nishiizumi et al., 1989) is based on Clark and Gillespie (1997), yielding an older calibration age and lower production rate than with the original calibration ages. The full calibration data is included in the Supplementary dataset.

For each site, the best-fit reference ${ }^{10} \mathrm{Be}$ production rate is determined for all five CRONUS production rate scaling schemes (Balco et al., 2008) by choosing the reference production rate that yields the lowest 
reduced chi-square value $\left(\chi_{R}^{2}\right)$ for the calculated individual sample exposure ages compared to the calibration age. The reduced chi-square statistics is a measure of clustering where lower values indicate stronger clustering and a value of 1 is expected if the scatter is caused by measurement uncertainty alone (cf. Balco, 2011). To avoid calibration sites with prior and/or incompete exposure, only calibration sites with $\chi_{R}^{2} \leq 2$ have been included in the global reference ${ }^{10} \mathrm{Be}$ production rate. The $\chi_{\mathrm{R}}^{2}$ value is calculated based on a fixed calibration age with no uncertainty because for each site the timing of initial exposure should be identical for all individual samples. The calibration age uncertainty is added in quadrature using standard uncertainty propagation to derive the individual site production rate uncertainty. For sites with more than three samples that yield $\chi_{R}^{2}>2$ (sites with significant production rate scatter) a maximum of $1 / 3$ of the samples have been excluded as outliers to achieve $\chi_{R}^{2} \leq 2$. Of all 24 sites, 21 sites yield $\chi_{R}^{2} \leq 2$ after outlier rejection of totally 12 samples for 7 sites, and 3 sites (Fig. 2: sites $G, I, R)$ are rejected from the global reference ${ }^{10} \mathrm{Be}$ production rate calculation because of too large scatter. Additionally, one site (Fig. 2: site F) with a significantly higher reference production rate than all other sites for all five production rate scaling schemes and no overlap within uncertainties with the average reference production rate is excluded as an outlier.

A global average is calculated using the same approach as in Balco et al. (2008), adopting the arithmetic mean and standard deviation of the remaining 20 calibration site reference ${ }^{10} \mathrm{Be}$ production rates as the global reference ${ }^{10} \mathrm{Be}$ production rate and uncertainty (Fig. 2; Table 1). With the arithmetic mean approach taken here, all of the 20 encompassed production rate calibration sites are given equal weight. Each of the individual site production rates is based on the assumption of no prior exposure and full exposure (under the assumed erosion rates) since the calibration event (Heyman et al., 2011b) and prior or incomplete exposure affecting all samples equally could yield too high or too low production rates, respectively. Further, the independent control on the calibration age vary from tightly clustered minimum and maximum radiocarbon ages to correlation to climate proxies, yielding production rates of varying reliability. However, the updated global production rates have a tighter clustering and are 9-11\% lower than the global CRONUS production rates (Balco et al., 2008) in agreement with recent lower ${ }^{10} \mathrm{Be}$ production rates (Balco et al., 2009; Putnam et al., 2010; Fenton et al., 2011; Kaplan et al., 2011; Briner et al., 2012; Goehring et al., 2012; Ballantyne and Stone, 2012; Young et al., 2013; Kelly et al., in press). Using the CRONUS calculator code for exposure age calculations, the global production rate uncertainties are taken to reflect a combined uncertainty from the individual site uncertainties as well as spatial and temporal production rate scaling, and they are used to derive the external exposure age uncertainty (Balco et al., 2008).

\section{Table 1}

Global reference spallation ${ }^{10} \mathrm{Be}$ production rates. All production rates are referenced to the 07KNSTD standardization (Nishiizumi et al., 2007).

\begin{tabular}{lll}
\hline $\begin{array}{l}\text { Production rate scaling } \\
\text { scheme (Balco et al., 2008) }\end{array}$ & $\begin{array}{l}\text { Reference spallation }{ }^{10}{ }^{B e} \\
\text { production rate }\left(\text { atoms }^{-1} \text { year }^{-1} \text { ) }\right.\end{array}$ & $\mathbf{X}^{2}{ }^{2}$ \\
\hline St & $3.99 \pm 0.22$ & 1.63 \\
De & $4.02 \pm 0.29$ & 11.26 \\
$\mathrm{Du}$ & $4.03 \pm 0.28$ & 9.92 \\
$\mathrm{Li}$ & $4.32 \pm 0.28$ & 8.73 \\
$\mathrm{Lm}$ & $3.94 \pm 0.20$ & 1.92 \\
\hline
\end{tabular}




\subsection{Exposure age compilation}

The compilation of Tibetan Plateau region ${ }^{10} \mathrm{Be}$ exposure ages is an updated and extended version of the dataset presented in Heyman et al. (2011b). All published ${ }^{10} \mathrm{Be}$ exposure ages from glacial deposits (including boulders, cobbles, and pebbles) formed by past glaciations on the Tibetan Plateau and surrounding mountains have been included. All exposure ages have been recalculated using the CRONUS online code (Balco et al., 2008) with the updated reference ${ }^{10} \mathrm{Be}$ production rates (Table 1), taking account of the various ${ }^{10} \mathrm{Be}$ standardizations used for the AMS measurements (Nishiizumi et al., 2007), and assuming zero erosion. For samples with multiple ${ }^{10} \mathrm{Be}$ measurements an error-weighted mean exposure age has been used. All exposure ages have been organized in groups where each group represents a discrete glacial deposit with a certain deglaciation age. The dataset includes ${ }^{10} \mathrm{Be}$ exposure ages from 485 glacial deposit groups with 1855 individual samples (1879 individual AMS measurements) (Table 2). The ${ }^{10} \mathrm{Be}$ exposure age dataset including CRONUS input and exposure ages is presented in the supplementary dataset. The adopted exposure ages in this study are derived from the time-dependent CRONUS Lm production rate scaling scheme (Balco et al., 2008) that has been shown to correlate well with production rate scaling based on analytical approximations to cosmic ray fluxes for low latitude, high altitude sites (Lifton et al., 2014).

Cosmogenic exposure dating involves significant uncertainties regarding the history of the sampled surface, commonly resulting in wide age scatter among samples from a discrete glacial deposit (Putkonen and Swanson, 2003; Chevalier et al., 2011; Heyman et al., 2011b). In an effort to assign a discrete deglaciation age to each group and to discriminate good exposure age groups from poor exposure age groups, each exposure age group has been classified into one of three classes based on the following criteria:

Class A: Multiple samples $(n \geq 3)$ that yield $\chi^{2}{ }_{R} \leq 2$ using the uncertainty-weighted average with analytical uncertainties (CRONUS internal uncertainty). The class $A$ exposure ages are assumed to correctly represent the deglaciation and an uncertainty-weighted mean, using the external uncertainty to allow comparison with distant sites, of the group exposure ages are assigned as deglaciation age. For groups with $\chi_{R}^{2}>2$, a maximum of $1 / 3$ of the group samples are allowed as outliers (still requiring $n \geq 3$ ) testing all possible combinations and using the least number of outliers that yield the lowest $\chi_{R}^{2} \leq 2$. The outlier exposure ages are assumed to be affected by geologic processes causing prior exposure or incomplete exposure. The deglaciation age uncertainty $(\sigma)$ is the deviation of all sample exposure ages (e), including outliers, from the adopted deglaciation age (a):

$\sigma=\sqrt{\frac{1}{n-1} \sum_{i=1}^{n}\left[e_{i}-a\right]^{2}}$

By including the outlier exposure ages in the uncertainty equation, exposure age scatter due to prior and/or incomplete exposure is reflected in the uncertainty.

Class B: Multiple samples ( $\mathrm{n} \geq 3$ ) that do not fulfill the criteria of class A but with a mean exposure age $\geq$ $85 \%$ of the oldest exposure age. The oldest exposure age is adopted as deglaciation age, assuming that incomplete exposure is the main factor causing exposure age scatter (Heyman et al., 2011b). For groups with a mean exposure age $<85 \%$ of the oldest exposure age, a maximum of $1 / 3$ of the group samples are allowed as outliers (still requiring $n \geq 3$ ) testing all possible combinations and using the least number of outliers that yield the oldest mean exposure age $\geq 85 \%$ of the oldest exposure age. Similar to class A, the deglaciation age uncertainty is the deviation of all sample exposure ages, including outliers, from the 
Table 2

List of references and number of dated samples and glacial deposits in the exposure age compilation. See Supplementary dataset for full sample information.

\begin{tabular}{|c|c|c|c|c|c|}
\hline Publication & Samples & $\begin{array}{l}\text { Glacial } \\
\text { deposits }^{a}\end{array}$ & Publication & Samples & $\begin{array}{l}\text { Glacial } \\
\text { deposits }^{\mathrm{a}}\end{array}$ \\
\hline Abramowski (2004) & 28 & 7 & Owen et al. (2003a) & 65 & 20 \\
\hline Abramowski et al. (2006) & 83 & 20 & Owen et al. (2003b) & 15 & 7 \\
\hline Amidon et al. (2013) & 10 & 3 & Owen et al. (2003c) & 18 & 7 \\
\hline Aoki and Imamura (1999) & 2 & 1 & Owen et al. (2005) & 63 & 18 \\
\hline Barnard et al. (2004a) & 15 & 4 & Owen et al. (2006a) & 56 & 17 \\
\hline Barnard et al. (2004b) & 15 & 6 & Owen et al. (2006b) & 42 & 11 \\
\hline Barnard et al. (2006) & 11 & 4 & Owen et al. (2009) & 56 & 9 \\
\hline Brown et al. (2002) & 4 & 1 & Owen et al. (2010) & 84 & 18 \\
\hline Chen et al. (2011) & 5 & 1 & Owen et al. (2012) & 73 & 12 \\
\hline Chevalier et al. (2005) & 27 & 3 & Phillips et al. (2000) & 14 & 10 \\
\hline Chevalier et al. (2011) & 222 & 32 & Pratt-Sitaula (2005) & 29 & 11 \\
\hline Colgan et al. (2006) & 3 & 3 & Pratt-Sitaula et al. (2011) & 24 & 6 \\
\hline Dong et al. (2014) & 15 & 2 & Röhringer et al. (2012) & 18 & 8 \\
\hline Dortch et al. (2010) & 22 & 3 & Schaefer et al. (2008) & 21 & 7 \\
\hline Dortch et al. (2013) & 46 & 10 & Schäfer (2000) & 1 & 1 \\
\hline Finkel et al. (2003) & 38 & 12 & Schäfer et al. (2002) & 9 & 5 \\
\hline Fu et al. (2013b) & 52 & 18 & Scherler et al. (2010) & 24 & 11 \\
\hline Gayer et al. (2006) & 4 & 3 & Scherler et al. (in press) & 2 & 2 \\
\hline Graf et al. (2008) & 17 & 9 & Seong et al. (2007) & 65 & 10 \\
\hline Hedrick et al. (2011) & 47 & 9 & Seong et al. (2009) & 124 & 25 \\
\hline Heyman et al. (2011a) & 51 & 15 & Strasky et al. (2009) & 5 & 4 \\
\hline Kong et al. (2009a) & 15 & 4 & Tschudi et al. (2003) & 2 & 1 \\
\hline Kong et al. (2009b) & 11 & 5 & Wang et al. (2003) & 1 & 1 \\
\hline Koppes et al. (2008) & 27 & 17 & Wang et al. (2006) & 1 & 1 \\
\hline Laserre et al. (2002) & 11 & 1 & Wang et al. (2013) & 22 & 5 \\
\hline Lee et al. (2014) & 24 & 5 & Xu et al. (2013) & 8 & 2 \\
\hline Li et al. (2011) & 11 & 5 & Zech (2012) & 13 & 4 \\
\hline Mériaux et al. (2004) & 44 & 8 & Zech et al. (2005) & 20 & 4 \\
\hline Murari et al. (2014) & 26 & 6 & Zech et al. (2009) & 17 & 8 \\
\hline Owen et al. (2001) & 24 & 13 & Zech et al. (2013) & 13 & 4 \\
\hline \multirow[t]{2}{*}{ Owen et al. (2002) } & 28 & 10 & Zhou et al. (2007) & 12 & 2 \\
\hline & & & $\Sigma$ & 1855 & $485^{a}$ \\
\hline
\end{tabular}

${ }^{\text {a }}$ A few glacial deposits have been dated in multiple studies.

adopted deglaciation age following equation 1. Thus, groups with larger exposure age scatter will have larger uncertainties.

Class C: Groups with one or two samples and larger groups that do not fulfill the criteria of class A and B. For single sample groups, the sample exposure age and the external uncertainty are adopted as deglaciation age and uncertainty. For groups with two samples that yield $\chi^{2} \leq 2$ the uncertaintyweighted mean age is adopted as deglaciation age. For all other multiple sample groups, the maximum exposure age is adopted as deglaciation age assuming that incomplete exposure is the main factor causing exposure age scatter (Heyman et al., 2011b). Class $C$ is the group of exposure ages with largest uncertainty due to small group size and/or large exposure age scatter. 


\section{3. $\triangle E L A$ approximation}

For each glacial deposit exposure age group the $\triangle E L A$ has been approximated based on a simplified version of the toe-to-headwall altitude ratio (THAR) methodology, assuming a THAR of 0.5 (cf. Benn et al., 2005; Braithwaite and Raper, 2009). Assuming that past and present glaciers had the equal highest altitudes, the $\triangle E L A$ can be calculated as the THAR of the difference between the present $\left(A_{\text {pres }}\right)$ and the past $\left(A_{\text {past }}\right)$ lowest altitude of the glaciers:

$\Delta \mathrm{ELA}=\left(A_{\text {pres }}-A_{\text {past }}\right) 0.5$

The equal highest altitude assumption implies that if past larger glaciers had maximum altitudes higher than the present-day glaciers, the $\triangle E L A$ will be a maximum estimate assuming equal past and present THAR. However, for mountain glaciers the uncertainty introduced by the equal highest altitude assumption is likely minor in comparison with the uncertainty inherent in the THAR methodology which takes no account of glacier mass balance or hypsometry (cf. Benn and Lehmkuhl, 2000). For glacial deposits where there are no present-day glaciers ( $17 \%$ of the glacial deposits), the $\triangle E L A$ is calculated with a present-day ELA assumed to coincide with the altitude of the upstream highest peak $\left(A_{\text {peak }}\right)$ :

$\Delta \mathrm{ELA}=\left(A_{\text {peak }}-A_{\text {past }}\right) 0.5$

Because the highest peak altitude in a non-glaciated region is a minimum altitude of a theoretical ELA, the $\triangle E L A$ for glacial deposits with no upstream present-day glaciers will be a minimum approximation.

For all glacial deposits, the location (latitude and longitude) and altitude of all lowest past and present (403 out of 485) glacier points and highest peak points have been recorded using Google Earth, with additional help of the SRTM elevation model, Landsat ETM+ satellite imagery, and the RGI glacier database (Arendt et al., 2012). This data is included in the Supplementary dataset.

To evaluate the uncertainty of the $\triangle E L A$ approximations, the THAR Google Earth-based $\triangle E L A$ approximations from 50 glacial deposits have been compared with published estimates of the $\triangle E L A$ for the same glacial deposits (Fig. 3). The difference between the Google Earth-based and the published
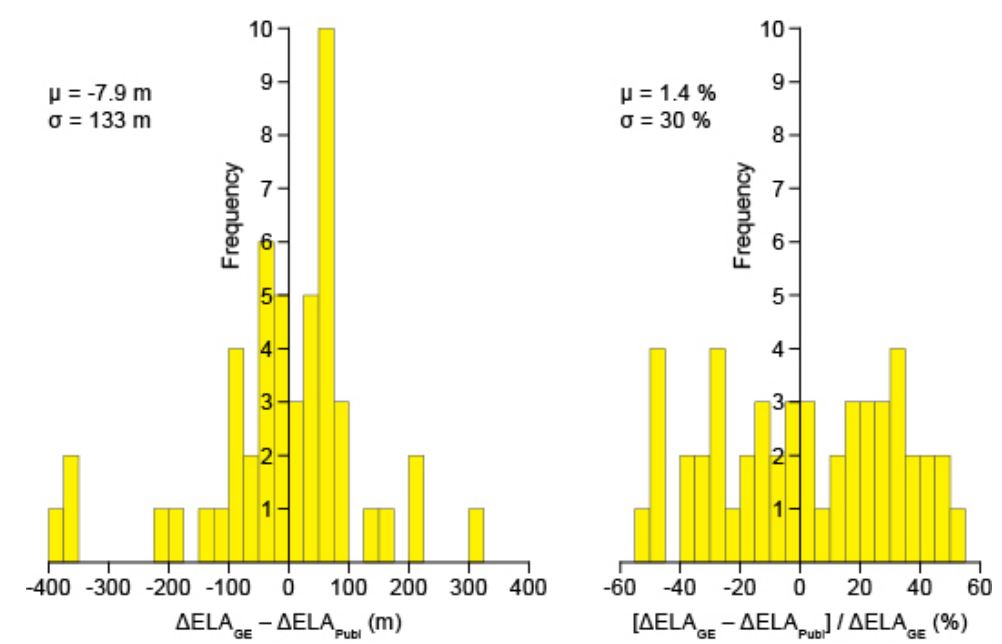

Fig. 3. Histograms of the difference between the THAR Google Earth-based $\triangle E L A$ estimates $\left(\triangle E L A_{G E}\right.$ ) and published $\triangle E L A$ estimates $\left(\triangle E L A_{\text {publ }}\right.$ ) based on a range of methods (see Supplementary dataset for full data). The $\triangle E L A$ difference is shown in meters (left) as well as in fraction of $\triangle E L A_{G E}$ (right). 
$\triangle$ ELA approximations scatter significantly, ranging up to $387 \mathrm{~m}$ or $55 \%$ of the Google Earth-based $\Delta \mathrm{ELA}$ approximations, but the average difference is close to the Google Earth-based $\triangle E L A$ approximations. The standard deviation of the fractional $\triangle$ ELA difference $(30 \%)$ is used as an estimate of the THAR Google Earth-based $\triangle$ ELA uncertainty.

\section{Results}

The glacial deposit deglaciation ages for the six regions are presented in Fig. 4. Fig. 5 shows the deglaciation ages and the associated $\triangle E L A$ approximations, and Fig. 6 shows the $\triangle E L A$ approximations in relation to the altitudinal range $A_{\text {peak }}-A_{\text {past }}$. The deglaciation ages of class $A, B$, and $C$ range up to $118 \mathrm{ka}$, $408 \mathrm{ka}$, and $636 \mathrm{ka}$, respectively, and the $\triangle \mathrm{ELA}$ approximations range up to $1440 \mathrm{~m}$. Of the 485 dated glacial deposits, 72 qualify for exposure age class $A$ (37 without outliers), 105 qualify for exposure age class B (42 without outliers), and 308 remain in class C (63 single sample groups, 93 two samples groups, and 152 multiple sample groups). There is a wide scatter in both deglaciation ages and $\triangle E L A$ approximations. However, $83 \%$ of all deglaciation ages are younger than $100 \mathrm{ka}$, and $85 \%$ of all $\triangle \mathrm{ELA}$ approximations are lower than $600 \mathrm{~m}$. The full dataset is included in the Supplementary dataset.

Fig. 7 shows probability density plots of the class $A$ and $B$ deglaciation ages and their $\triangle E L A$ approximations divided into three temporal groups: glacial deposits with deglacial ages $<10 \mathrm{ka}, 10-30 \mathrm{ka}$, and $>30 \mathrm{ka}$. The class $\mathrm{C}$ exposure ages are excluded because of their large exposure age scatter and small sample groups. Fig. 8 shows the probability density plots and $\triangle E L A$ approximations divided into the nine spatial regions (Fig. 1). Fig. 9 shows the spatial distribution of the class $A$ and $B$ deglaciation ages for the three temporal groups.

Only four regions have class $A$ and $B$ deglaciation ages $<10$ ka (Figs. 4, 8, 9): the E Pamir - Karakoram region ( $n=12)$, the W Tibet region $(n=1)$, the W Himalaya region $(n=3)$, and the C Himalaya region $(n=$ 8). All nine regions have some class $A$ and $B$ deglaciation ages in the 10-30 ka rage, with a total of 89
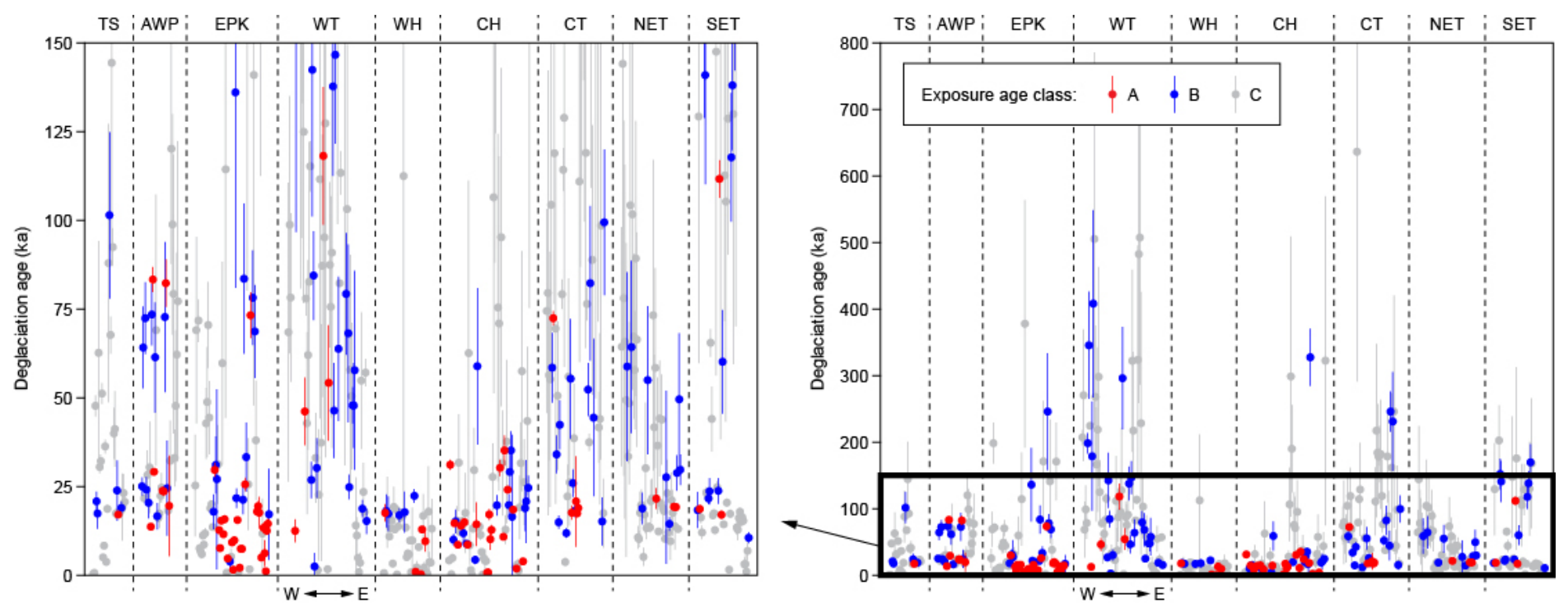

Fig. 4. Deglaciation age for all 485 dated glacial deposits on the Tibetan Plateau divided into the nine different regions (Fig. 1). Within each region, the deglaciation ages are ordered based on longitude. 

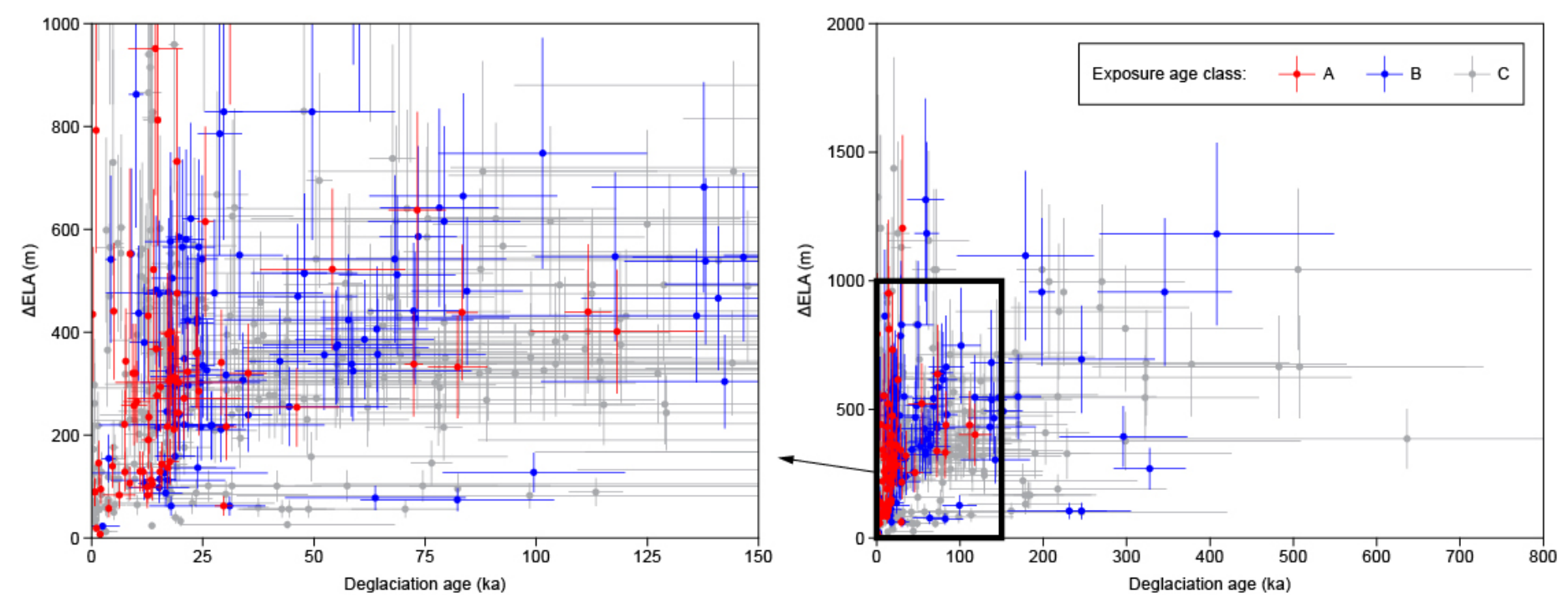

Fig. 5. Deglaciation age and $\triangle E L A$ estimates for all 485 dated glacial deposits on the Tibetan Plateau.

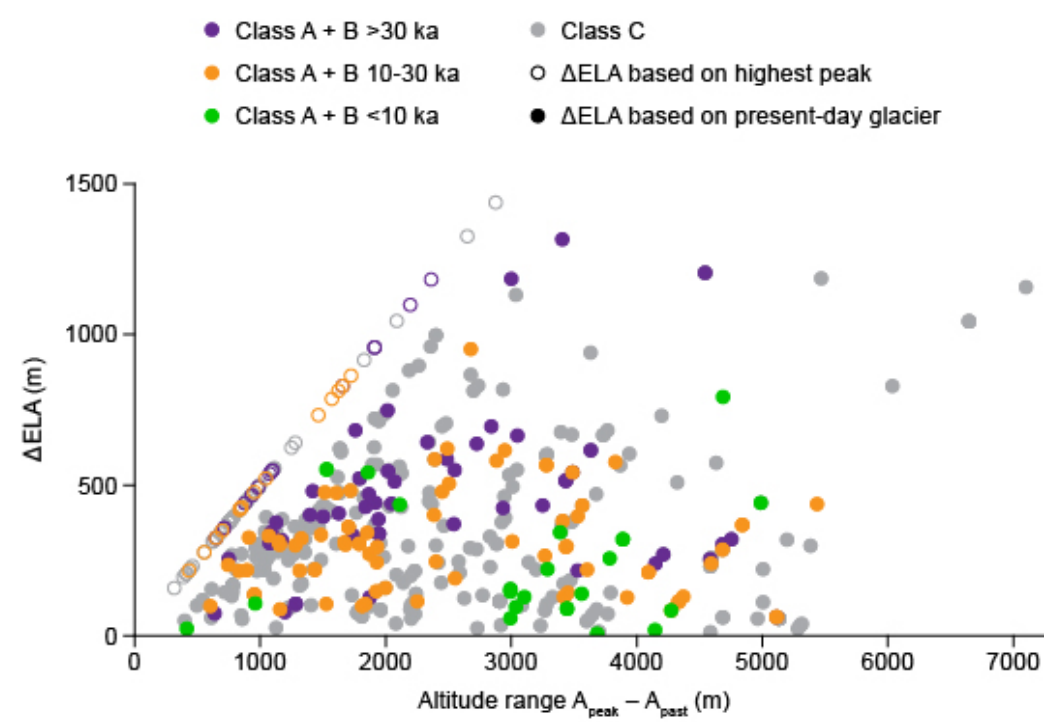

Fig. 6. $\triangle E L A$ approximations in relation to the altitudinal range $A_{\text {peak }}-A_{\text {past }}$. The glacial deposits with class $A$ and $B$ exposure age groups are displayed divided into three temporal groups (cf. Fig. 7). The $\Delta E L A$ based on the highest peak altitudes are minimum estimates of the $\triangle E L A$.

deglacation ages. There are somewhat fewer class A and B deglaciation ages older than $30 \mathrm{ka}(\mathrm{n}=64)$, and the ages generally scatter more. The most well-clustered group of $>30$ ka class $A$ and $B$ deglaciation ages occurs in the Alay - W Pamir and the E Pamir - Karakoram region with 11 deglaciation ages ranging from 61 ka to 84 ka (Figs. 4, 8).

The $\triangle E L A$ approximations within the three temporal groups generally scatter significantly (Figs. 6-8). The $\triangle$ ELA mean and standard deviation for the $<10 \mathrm{ka}, 10-30 \mathrm{ka}$, and $>30 \mathrm{ka}$ class $\mathrm{A}$ and $\mathrm{B}$ deglaciation age groups are $247 \pm 211 \mathrm{~m}, 337 \pm 197 \mathrm{~m}$, and $494 \pm 280 \mathrm{~m}$, respectively (Fig. 7). 

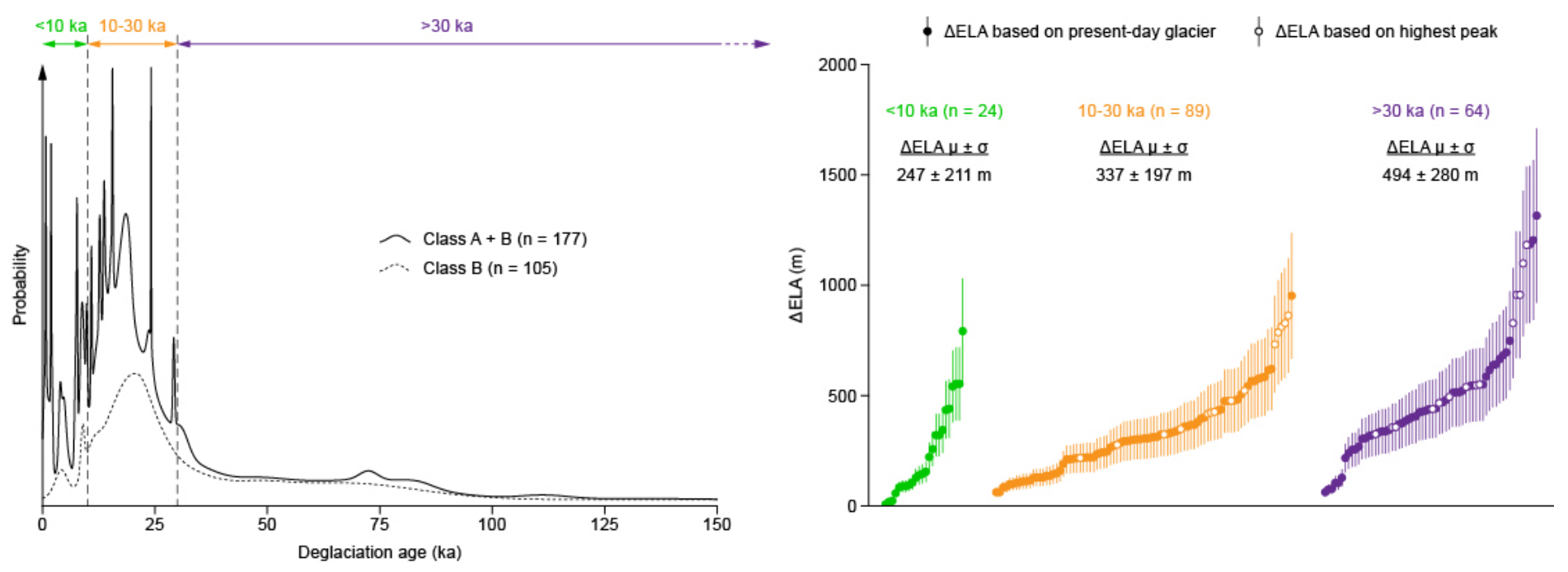

Fig. 7. Probability density plots of the class $A$ and $B$ deglaciation ages and the associated $\triangle E L A$ estimates divided into three temporal groups. The $\triangle E L A$ estimates are ordered from the lowest to the highest $\triangle E L A$. The $\triangle E L A$ based on the highest peak altitudes are minimum estimates of the $\triangle E L A$.

All exposure ages have been calculated using the CRONUS $\mathrm{Lm}{ }^{10} \mathrm{Be}$ production rate scaling scheme, and using alternative production rates scaling schemes yield different exposure ages (Balco et al., 2008; Owen and Dortch, 2014). With the updated global reference production rates, the CRONUS St constant production rate scaling scheme yields exposure ages on average $7 \%$ older than the CRONUS Lm exposure ages for the study region exposure ages. The time-dependent CRONUS De, Du, and Li production rate scaling schemes yield exposure ages on average 5-7\% younger than the CRONUS Lm exposure ages (Supplementary dataset). For precise chronologies the uncertainty regarding production rate scaling can be problematic. In this study with a focus on the general chronology, however, the uncertainty regarding production rate scaling will only have minor effects on the outcome.

\section{Discussion}

The Tibetan Plateau region exposure age record is to a large part composed of glacial deposits with high single deposit exposure age scatter. Of all glacial deposits with a minimum of three dated samples $(\mathrm{n}=$ 329) $22 \%$ qualify for class $A$ and $32 \%$ qualify for class $B$, leaving $46 \%$ in class $C$ even after outlier rejection (Fig. 4). Without outlier rejection, only $11 \%$ qualify for class $A$ and $19 \%$ qualify for class $B$, leaving $70 \%$ in class $\mathrm{C}$. The high exposure age scatter yielding these low numbers of well-clustered exposure age groups must be explained by prior exposure and/or incomplete exposure due to geological processes diverging from an ideal exposure dating case. Based on the temporal pattern of single deposit scatter and the limited amount of prior exposure in deposits of known deglaciation age, incomplete exposure due to post-glacial geomorphic processes is likely the main factor causing exposure age scatter (Heyman et al., 2011b). This is also in line with the fact that a large part of the Tibetan Plateau region glacial deposits appear to have formed prior to the global last glacial maximum (Schäfer et al., 2002; Owen et al., 2006a, 2006b; Dortch et al., 2010, 2013; Heyman et al., 2011a; Zech et al., 2013) and 

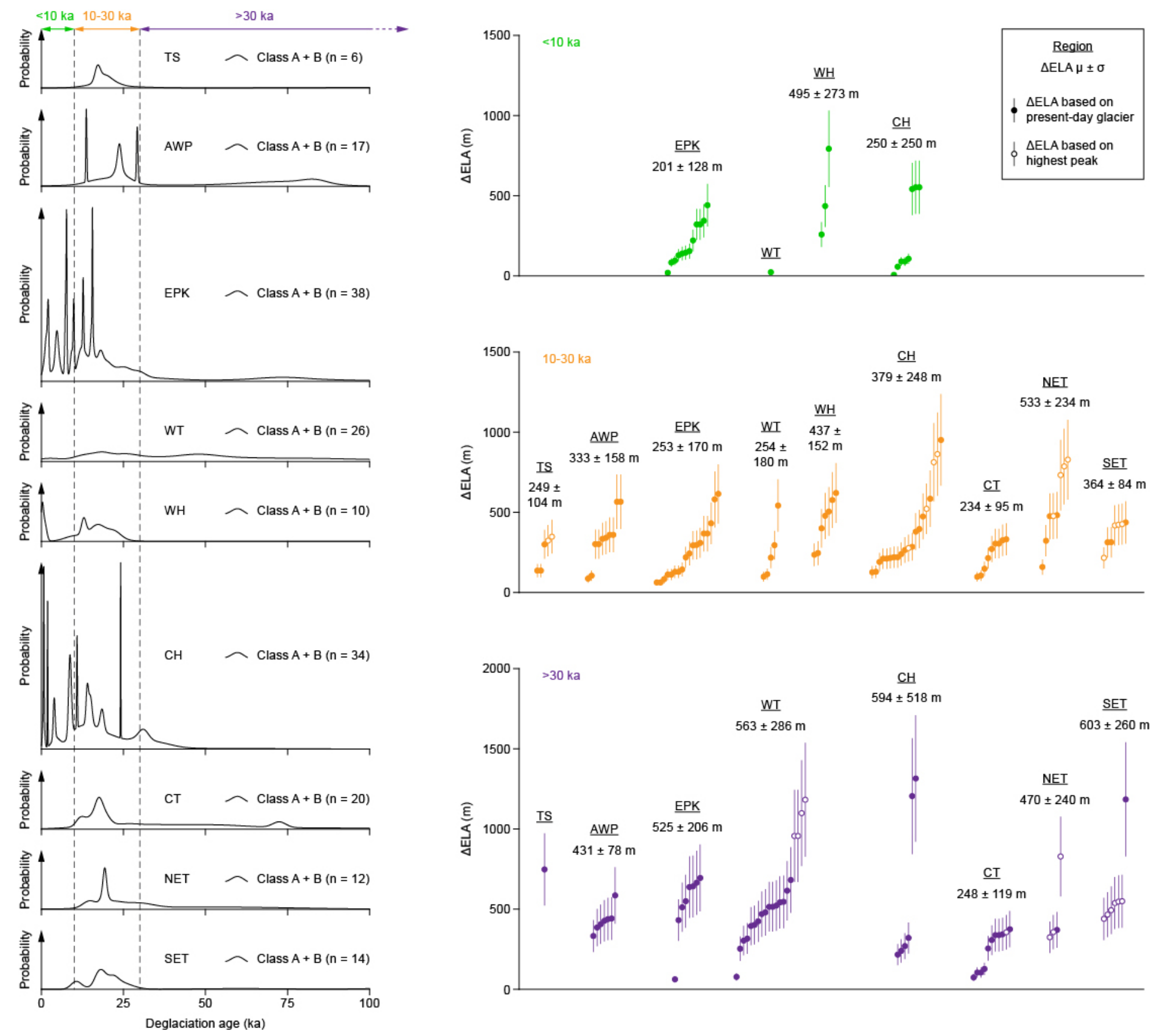

Fig. 8. Probability density plots of the class $A$ and $B$ deglaciation ages for each of the six regions and their associated $\triangle E L A$ estimates divided into three temporal groups. The $\triangle E L A$ estimates are ordered from the lowest to the highest $\triangle E L A$. The $\triangle E L A$ based on the highest peak altitudes are minimum estimates of the $\triangle E L A$. Fig. 1 shows the location and full name of the nine regions.

therefore have had a long duration for geomorphic processes disturbing an ideal full post-glacial exposure.

The assigned deglaciation ages of exposure age groups A, B, and C have mean uncertainties of $15 \%, 27$ $\%$, and $35 \%$, respectively, reflecting the higher single deposit exposure age scatter and uncertainty of group $B$ and $C$. Because of the large exposure age scatter and uncertainty (or low number of samples) for group $C$, the deglaciation ages and $\triangle E L A$ depression estimates of these groups are discarded in the 
following discussions. The assigned deglaciation ages and uncertainties of group A and B are assumed to capture the actual deglaciation ages for the glacial deposits. There are likely individual glacial deposits with erroneous deglaciation ages due to prior or incomplete exposure. The main part of the assigned deglaciation ages for group $A$ and $B$ are however thought to capture the actual deglaciation ages within the uncertainties because of the conservative uncertainty estimation including all outliers.

The clustering of class A and B deglaciation ages in the 10-30 ka range (Figs. 4, 7, 8) indicates that glaciers advanced during the time frame of the global last glacial maximum (LGM) and the subsequent deglaciation of the Laurentide and Scandinavian ice sheets. For the Tian Shan and the C, NE, and SE Tibet regions the peak of the class $A$ and $B$ deglaciation ages occur between $17 \mathrm{ka}$ and $20 \mathrm{ka}$, while the Alay W Pamir, E Pamir - Karakoram and the $\mathrm{W}$ and $\mathrm{C}$ Himalaya regions have somewhat more scattered peaks in the 10-30 ka range (Fig. 8). The W Tibet region has the least pronounced peak in the 10-30 ka range (Fig. 8). A significant part of all glacial deposits have deglaciation ages $>30$ ka (Figs. 4, 5), confirming that the glacial imprint on the Tibetan Plateau region to a large degree predates the LGM. However, the wide exposure age scatter for the pre-LGM glacial deposits, probably caused primarily by incomplete exposure (Heyman et al., 2011b), generally prohibits well-constrained chronological definition of pre-LGM plateauwide or regional glaciations (Figs. 4, 7, 8). The tightest pre-LGM age clustering occurs in the westernmost regions of the study area with eleven deglaciation ages between $61 \mathrm{ka}$ and $84 \mathrm{ka}$, in line with previous suggestions of glacial advance in these regions during marine isotope stage 4 (Owen et al., 2008, 2012; Zech et al., 2013).

The spatial distribution of well-clustered ages $<10 \mathrm{ka}$, with glacial deposits confined to the southern and western parts of the Tibetan Plateau region (Fig. 9), could potentially indicate more significant Holocene glacier advances in these regions. The lack of well-clustered Holocene ages in other regions could however also be a result of a stronger focus on older glaciations with Holocene glacial deposits not being sampled. For the 10-30 ka period, the glacial deposits with well-clustered ages are generally distributed along the marginal mountain ranges of the Tibetan Plateau, and there is a lack of class A ages in the inner and northern plateau regions (Fig. 9). This can potentially indicate that while glaciers along the plateau margins advanced during the LGM, glaciers in the central and northern plateau regions did not expand much more than to present-day extents (Schäfer et al., 2002; Owen et al., 2005; Colgan et al., 2006; Heyman et al., 2011a; Amidon et al., 2013). For the $>30$ ka period, there are glacial deposits with class B (primarily) and $A$ ages across most of the study region (Fig. 9), indicating that maximum glaciations of the Tibetan Plateau and the surrounding mountains predate the LGM.
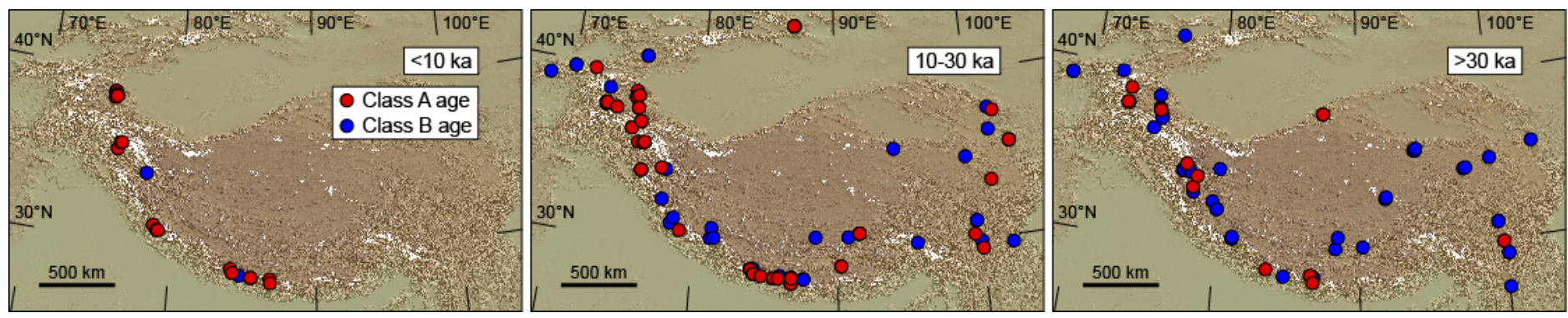

Fig. 9. Spatial distribution of the class $A$ and $B$ deglaciation ages for the three temporal groups $<10 \mathrm{ka}, 10-30 \mathrm{ka}$, and $>30$ ka. 
The chronological approach used here with $\chi_{\mathrm{R}}^{2}$ and mean/max exposure age tests differs from the kernel density smoothing approach of two recent studies investigating the timing of glaciation across the Tibetan Plateau region (Dortch et al., 2013; Murari et al., 2014). Dortch et al. (2013) and Murari et al. (2014) defined 19 and 27 regional glacial stages for the western and southern/eastern parts of the Tibetan Plateau region, respectively, ranging up to more than $300 \mathrm{ka}$ in age. Both approaches yield a large number of ages in the 10-30 ka range and considerable variation across the Tibetan Plateau and the surrounding mountains. However, the more conservative uncertainty estimates used here for scattered exposure age groups highlights the difficulty to accurately define the timing of pre-LGM glaciations in the Tibetan Plateau region (Figs. 7 and 8).

The large scatter in $\triangle E L A$ estimates (Figs. 5-8) is likely a result of several factors. The Tibetan Plateau is an extensive region comprising widely different climatic and topographic settings (Fig. 1). Local climate and topography may have a profound impact on the ELA due to different mass balance regimes and factors such as aspect, avalanches, and debris cover (Benn and Lehmkuhl, 2000; Benn et al., 2005; Owen and Benn, 2005). The $\triangle E L A$ estimates are based on a highly simplified glacier altitude assumption taking no account of glacier type and local environment that may influence the THAR (Benn and Lehmkuhl, 2000). While the average deviation from published $\triangle E L A$ values is close to zero (Fig. 3 ), the scatter suggests a significant uncertainty in the $\triangle E L A$ estimates. Further, the glacial deposits for which the $\triangle E L A$ has been estimated represent a temporal range of very young (historical times) to very old (multiple glacial cycles back in time) glaciations. Within each of the three temporal groups of the $\triangle E L A$ estimates (Figs. 7 and 8), the paleoclimate has most likely varied significantly (Thompson et al., 1997) resulting in varying $\triangle E L A$ (cf. Owen and Benn, 2005). Finally, glacial deposits with prior and/or incomplete exposure that still yield well-clustered ages may yield inaccurate $\triangle E L A$ estimates for the apparent deglaciation age. The lack of a clear relationship to the altitudinal range $A_{\text {peak }}-A_{\text {past }}$ for the three temporal groups (Fig. 6) may indicate that topography is not a first order factor for the timing of glacier advances as suggested by Amidon et al. (2013).

Given the large scatter and uncertainty of the $\triangle E L A$ estimates, the results should be interpreted with care. The generally low $\triangle E L A$ estimates, however, suggest limited past glacier advances. For the entire study area, average and standard deviation of the $\triangle E L A$ estimates is $337 \pm 197 \mathrm{~m}$ for the group $\mathrm{A}$ and $\mathrm{B}$ 10-30 ka deglaciation ages and $494 \pm 280 \mathrm{~m}$ for the group $A$ and $B>30$ ka deglaciation ages (Fig. 7). There is considerable regional variation in the $\triangle E L A$ estimates (Fig. 8). For the 10-30 ka period, the average regional $\triangle E L A$ estimates range from $234 \pm 95 \mathrm{~m}$ for $C$ Tibet to $533 \pm 234 \mathrm{~m}$ for NE Tibet. For the $>30 \mathrm{ka}$ period, the average regional $\triangle E L A$ estimates range from $248 \pm 119 \mathrm{~m}$ for C Tibet to $603 \pm 260 \mathrm{~m}$ for SE Tibet. The particularly low $\triangle E L A$ estimates for the central Tibetan Plateau is in line with previous reconstructions suggesting more pronounced precipitation reduction in the inner regions of the Tibetan Plateau during past glaciations (Shi, 2002; Lehmkuhl and Owen, 2005; Amidon et al., 2013). The $\Delta \mathrm{ELA}$ estimates for the 10-30 ka period (Figs. 7, 8) are generally lower than previous LGM reconstructions (Shi, 2002; Lehmkuhl and Owen, 2005; Mark et al., 2005). This is probably a result of improved temporal constraints of the glacial deposits, with previous reconstructions including $\triangle E L A$ estimates of more extensive pre-LGM glaciations (cf. Owen and Benn, 2005).

The $\triangle E L A$ is a result of past and present climate and glacier evolution, but to directly translate $\triangle E L A$ into paleoclimate is difficult because both temperature and precipitation affect mass balance. Assuming no change in precipitation during past glaciations and a lapse rate of $-0.006^{\circ} \mathrm{C} \mathrm{m}^{-1}$, the $\Delta$ ELA estimates (Fig. 
7) corresponds to a cooling of $2.0 \pm 1.2{ }^{\circ} \mathrm{C}$ for the $10-30$ ka glacial deposits and a cooling of $3.0 \pm 1.7{ }^{\circ} \mathrm{C}$ for the $>30$ ka glacial deposits. These cooling values are lower than some previous estimates for Tibetan Plateau glacial cooling (Yao et al., 2000; Liu et al., 2002; Shi, 2002; Böhner and Lehmkuhl, 2005), but confirms limited cooling based on biogeographical proxies (Miehe et al., 2011; Schmidt et al., 2011) and atmospheric modeling (Zheng et al., 2004; Jiang et al., 2011). However, past Tibetan Plateau glacial periods were likely drier than today (Herzschuh, 2006), limiting glacier accumulation. Further, in an extremely dry climate, sublimation may be responsible for a major part of the glacier ablation, limiting glacier growth even under significant cooling (Rupper and Roe, 2008). Therefore, the $\triangle E L A$ based cooling reconstructions should be seen as minimum estimates.

\section{Conclusions}

Compilation and recalibration of ${ }^{10} \mathrm{Be}$ production rates for 24 sites yields updated global reference ${ }^{10} \mathrm{Be}$ production rates that are lower and have tighter clustering than the global CRONUS production rates (Balco et al., 2008) in line with several recent calibration studies.

Analysis of 1855 recalculated ${ }^{10} \mathrm{Be}$ exposure ages and $\triangle \mathrm{ELA}$ estimates from 485 glacial deposits on the Tibetan Plateau can potentially enable quantification of the timing and degree of past glacial advances. A large majority of all glacial deposits with multiple samples have exposure age scatter that must be explained by prior and/or incomplete exposure. An extensive and wide exposure age record indicates that glaciers on the Tibetan Plateau have advanced multiple times over the last few hundred thousand years. The temporally best constrained glacier advances appear to coincide with the global LGM and the deglaciation of the northern Hemisphere ice sheets. A large part of the glacial geological record on the Tibetan Plateau predates the global LGM, but the timing of the pre-LGM glaciations is difficult to constrain accurately because of wide exposure age scatter. The paleoglaciations of the Tibetan Plateau have generally been limited, with average $\triangle \mathrm{ELA}$ of $337 \pm 197 \mathrm{~m}$ for LGM glacial deposits and $494 \pm 280$ for pre-LGM glacial deposits.

\section{Acknowledgements}

Thanks to Lewis Owen and an anonymous reviewer for constructive reviews, and to the Swedish Research Council for postdoctoral research funding.

\section{References}

Abramowski, U., 2004. The use of ${ }^{10} \mathrm{Be}$ surface exposure dating of erratic boulders in the reconstruction of the late Pleistocene glaciation history of mountainous regions, with examples from Nepal and Central Asia. PhD thesis, University of Bayreuth.

Abramowski, U., Bergau, A., Seebach, D., Zech, R., Glaser, B., Sosin, P., Kubik, P.W., Zech, W., 2006. Pleistocene glaciations of central Asia: results from ${ }^{10} \mathrm{Be}$ surface exposure ages of erratic boulders from the Pamir (Tajikistan), and the Alay-Turkestan range (Kyrgyzstan). Quat. Sci. Rev. 25, 1080-1096. 
Amidon, W.H., Bookhagen, B., Avouac, J.-P., Smith, T., Rood, D., 2013. Late Pleistocene glacial advances in the western Tibet interior. Earth Planet. Sci. Lett. 381, 210-221.

Aoki, T., Imamura, M., 1999. Reconstructing the glacial chronology based on the ${ }^{10} \mathrm{Be}$ exposure age - the case study of the Khumbu Glacier, eastern Nepal Himalayas. Bull. Natl. Mus. Jpn. Hist. 81, 517-525.

Arendt, A., Bolch, T., Cogley, J.G., Gardner, A., Hagen, J.-O., Hock, R., Kaser, G., Pfeffer, W.T., Moholdt, G., Paul, F., Radić, V., Andreassen, L., Bajracharya, S., Barrand, N., Beedle, M., Berthier, E., Bhambri, R., Bliss, A., Brown, I., Burgess, D., Burgess, E., Cawkwell, F., Chinn, T., Copland, L., Davies, B., De Angelis, H., Dolgova, E., Filbert, K., Forester, R., Fountain, A., Frey, H., Giffen, B., Glasser, N., Gurney, S., Hagg, W., Hall, D., Haritashya, U.K., Hartmann, G., Helm, C., Herreid, S., Howat, I., Kapustin, G., Khromova, T., Kienholz, C., König, M., Kohler, J., Kriegel, D., Kutuzov, S., Lavrentiev, I., Le Bris, R., Lund, J., Manley, W., Mayer, C., Miles, E., Li, X., Menounos, B., Mercer, A., Mölg, N., Mool, P., Nosenko, G., Negrete, A., Nuth, C., Pettersson, R., Racoviteanu, A., Ranzi, R., Rastner, P., Rau, F., Raup, B.H., Rich, J., Rott, H., Schneider, C., Seliverstov, Y., Sharp, M., Sigurđsson, O., Stokes, C., Wheate, R., Winsvold, S., Wolken, G., Wyatt, F., Zheltyhina, N., 2012. Randolph Glacier Inventory - A dataset of global glacier outlines: Version 3.2. Global Land Ice Measurements from Space, Boulder Colorado, USA. Digital Media.

Balco, G., 2011. Contributions and unrealized potential contributions of cosmogenic-nuclide exposure dating to glacier chronology, 1990-2010. Quat. Sci. Rev. 30, 3-27.

Balco, G., Stone, J.O., Lifton, N.A., Dunai, T.J., 2008. A complete and easily accessible means of calculating surface exposure ages or erosion rates from ${ }^{10} \mathrm{Be}$ and ${ }^{26} \mathrm{Al}$ measurements. Quat. Geochronol. 3, 174-195.

Balco, G., Briner, J., Finkel, R.C., Rayburn, J.A., Ridge, J.C., Schaefer, J.M., 2009. Regional beryllium-10 production rate calibration for late-glacial northeastern North America. Quat. Geochronol. 4, 93-107.

Ballantyne, C.K., Stone, J.O., 2012. Did large ice caps persist on low ground in north-west Scotland during the lateglacial interstade? J. Quat. Sci. 27, 297-306.

Barnard, P.L., Owen, L.A., Finkel, R.C., 2004a. Style and timing of glacial and paraglacial sedimentation in a monsoon-influenced high Himalayan environment, the upper Bhagirathi Valley, Garhwal Himalaya. Sediment. Geol. 165, 199-221.

Barnard, P.L., Owen, L.A., Sharma, M.C., Finkel, R.C., 2004b. Late Quaternary (Holocene) landscape evolution of a monsoon-influenced high Himalayan valley, Gori Ganga, Nanda Devi, NE Garhwal. Geomorphology 61, 91-110.

Barnard, P.L., Owen, L.A., Finkel, R.C., Asahi, K., 2006. Landscape response to deglaciation in a high relief, monsooninfluenced alpine environment, Langtang Himal, Nepal. Quat. Sci. Rev. 25, 2162-2176.

Benn, D.I., Lehmkuhl, F., 2000. Mass balance and equilibrium-line altitudes of glaciers in high-mountain environments. Quat. Int. 65/66, 15-29.

Benn, D.I., Owen, L.A., Osmaston, H.A., Seltzer, G.O., Porter, S.C., Mark, B., 2005. Reconstruction of equilibrium-line altitudes for tropical and sub-tropical glaciers. Quat. Int. 138-139, 8-21.

Böhner, J., Lehmkuhl, F., 2005. Environmental change modelling for central and high Asia: Pleistocene, present and future scenarios. Boreas 34, 220-231.

Braithwaite, R.J., Raper, S.C.B., 2009. Estimating equilibrium-line altitude (ELA) from glacier inventory data. Ann. Glaciol. 50, 127-132.

Briner, J.P., Young, N.E., Goehring, B.M., Schaefer, J.M., 2012. Constraining Holocene ${ }^{10}$ Be production rates in Greenland. J. Quat. Sci. 27, 2-6.

Bronk Ramsey, C., 2009. Bayesian analysis of radiocarbon dates. Radiocarb. 51, 337-360. 
Brown, E.T., Bendick, R., Bourlès, D.L., Gaur, V., Molnar, P., Raisbeck, G.M., Yiou, F., 2002. Slip rates of the Karakorum fault, Ladakh, India, determined using cosmic ray exposure dating of debris flows and moraines. J. Geophys. Res. 107, B9 2192.

Chen, Y.X., Li, Y.K.,Zhang, M., Zhang, J.C., Liu, G.N., 2011. Terrestrial cosmogenic nuclide ${ }^{10}$ Be exposure ages of the samples from Wangkun till in the Kunlun Pass. J. Glac. Geocryol. 33, 101-109. [In Chinese with English abstract]

Chevalier, M.-L., Ryerson, F.J., Tapponnier, P., Finkel, R.C., Van der Woerd, J., Li H.B., Liu, Q., 2005. Slip-rate measurements on the Karakorum Fault may imply secular variations in Fault motion. Science 307, 411-414.

Chevalier, M.-L., Hilley, G., Tapponnier, P., Van der Woerd, J., Jing, L.Z., Finkel, R.C., Ryerson, F.J., Li, H.B., Liu, X.H., 2011. Constraints on the late Quaternary glaciations in Tibet from cosmogenic exposure ages of moraine surfaces. Quat. Sci. Rev. 30, 528-554.

Christensen, J.H., Hewitson, B., Busuioc, A., Chen, A., Gao, X., Held, I., Jones, R., Kolli, R.K., Kwon, W.-T., Laprise, R., Magaña Rueda, V., Mearns, L., Menéndez, C.G., Räisänen, J., Rinke, A., Sarr, A., Whetton, P., 2007. Regional Climate Projections. In: Solomon, S., Qin, D., Manning, M., Chen, Z., Marquis, M., Averyt, K.B., Tignor, M., Miller, H.L. (Eds.), Climate Change 2007: The Physical Science Basis. Cambridge University Press, Cambridge, UK and New York, USA, pp. 847-940.

Clark, D.H., Gillespie, A.R., 1997. Timing and significance of late-glacial and Holocene cirque glaciation in the Sierra Nevada, California. Quat. Int. 38/39, 21-38.

Colgan, P.M., Munroe, J.S., Zhou, S.Z., 2006. Cosmogenic radionuclide evidence for the limited extent of last glacial maximum glaciers in the Tanggula Shan of the central Tibetan Plateau. Quat. Res. 65, 336-339.

Dong, G.C., Yi, C.L., Caffee, M., 2014. ${ }^{10}$ Be dating of boulders on moraines from the last glacial period in the Nyainqentanglha mountains, Tibet. Sci. China Earth Sci. 57, 221-231.

Dortch, J.M., Owen, L.A., Caffee, M.W., 2010. Quaternary glaciation in the Nubra and Shyok valley confluence, northernmost Ladakh, India. Quat. Res. 74, 132-144.

Dortch, J.M., Owen, L.A., Caffee, M.W., 2013. Timing and climatic drivers for glaciation across semi-arid western Himalayan-Tibetan orogen. Quat. Sci. Rev. 78, 188-208.

Farber, D.L., Hancock, G.S., Finkel, R.C., Rodbell, D.T., 2005. The age and extent of tropical alpine glaciation in the Cordillera Blanca, Peru. J. Quat. Sci. 20, 759-776.

Fenton, C.R., Hermanns, R.L., Blikra, L.H., Kubik, P.W., Bryant, C., Niedermann, S., Meixner, A., Goethals, M.M., 2011. Regional ${ }^{10} \mathrm{Be}$ production rate calibration for the past $12 \mathrm{ka}$ deduced from the radiocarbon-dated Grøtlandsura and Russenes rock avalanches at $69^{\circ}$ N, Norway. Quat. Geochronol. 6, 437-452.

Finkel, R.C., Owen, L.A., Barnard, P.L., Caffee, M.W., 2003. Beryllium-10 dating of Mount Everest moraines indicates a strong monsoon influence and glacial synchroneity throughout the Himalaya. Geology 31, 561-564.

Fu, P., Harbor, J.M., Stroeven, A.P., Hättestrand, C., Heyman, J., Zhou, L.P., 2013a. Glacial geomorphology and paleoglaciation patterns in Shaluli Shan, the southeastern Tibetan Plateau - evidence for polythermal ice cap glaciation. Geomorphology 182, 66-78.

Fu, P., Stroeven, A.P., Harbor, J.M., Hättestrand, C., Heyman, J., Caffee, M.W., Zhou, L.P., 2013b. Paleoglaciation of Shaluli Shan, southeastern Tibetan Plateau. Quat. Sci. Rev. 64, 121-135.

Gayer, E., Lavé, J., Pik, R., France-Lanord, C., 2006. Monsoonal forcing of Holocene glacier fluctuations in Ganesh Himal (central Nepal) constrained by cosmogenic 3He exposure ages of garnets. Earth Planet. Sci. Lett. 252, 275288.

Goehring, B.M., Lohne, Ø.S., Mangerud, J., Svendsen, J.I., Gyllencreutz, R., Schaefer, J., Finkel, R., 2012. Late glacial and Holocene ${ }^{10}$ Be production rates for western Norway. J. Quat. Sci. 27, 89-96. 
Gosse, J.C., Evenson, E.B., Klein, J., Lawn, B., Middleton, R., 1995. Precise cosmogenic ${ }^{10}$ Be measurements in western North America: support for a global Younger Dryas cooling event. Geology 23, 877-880.

Graf, A.A., Strasky, S., Zhao, Z.Z., Akçar, N., Ivy-Ochs, S., Kubik, P.W., Christl, M., Kasper, H.U., Wieler, R., Schlüchter, C., 2008. Glacier extension on the eastern Tibetan Plateau in response to MIS 2 cooling, with a contribution to ${ }^{10} \mathrm{Be}$ and ${ }^{21} \mathrm{Ne}$ methodology, in: Strasky, S., Glacial response to global climate changes: cosmogenic nuclide chronologies from high and low latitudes. PhD thesis, ETH Zürich.

Harrison, T.M., Copeland, P., Kidd, S.F., Yin, A., 1992. Raising Tibet. Science 255, 1663-1670.

Hedrick, K.A., Seong, Y.B., Owen, L.A., Caffee, M.W., Dietsch, C., 2011. Towards defining the transition in style and timing of Quaternary glaciation between the monsoon-influenced Greater Himalaya and the semi-arid Transhimalaya of Northern India. Quat. Int. 236, 21-33.

Herzschuh, U., 2006. Palaeo-moisture evolution in monsoonal central Asia during the last 50,000 years. Quat. Sci. Rev. 25, 163-178.

Heyman, J., Stroeven, A.P., Alexanderson, H., Hättestrand, C., Harbor, J., Li, Y.K., Caffee, M.W., Zhou, L.P., Veres, D., Liu, F., Machiedo, M., 2009. Palaeoglaciation of Bayan Har Shan, northeastern Tibetan Plateau: glacial geology indicates maximum extents limited to ice cap and ice field scales. J. Quat. Sci. 24, 710-727.

Heyman, J., Stroeven, A.P., Caffee, M.W., Hättestrand, C., Harbor, J.M., Li, Y.K., Zhou, L.P., Hubbard, A., 2011 a. Palaeoglaciology of Bayan Har Shan, NE Tibetan Plateau: exposure ages reveal a missing LGM expansion. Quat. Sci. Rev. 30, 1988-2001.

Heyman, J., Stroeven, A.P., Harbor, J., Caffee, M.W., 2011b. Too young or too old: evaluating cosmogenic exposure dating based on an analysis of compiled boulder exposure ages. Earth Planet. Sci. Lett. 302, 71-80.

Hogg, A.G., Hua, Q., Blackwell, P.G., Niu, M., Buck, C.E., Guilderson, T.P., Heaton, T.J., Palmer, J.G., Reimer, P.J., Reimer, R.W., Turney, C.S.M., Zimmerman, S.R.H., 2013. SHCal13 Southern Hemisphere calibration, 0-50,000 years cal BP. Radiocarb. 55, 1889-1903.

Jiang, D.B., Lang, X.M., Tian, Z.P., Guo, D.L., 2011. Last glacial maximum climate over China from PMIP simulations. Palaeogeogr. Palaeoclimatol. Palaeoecol. 309, 347-357.

Kaplan, M.R., Strelin, J.A., Schaefer, J.M., Denton, G.H., Finkel, R.C., Schwartz, R., Putnam, A.E., Vandergoes, M.J., Goehring, B.M., Travis, S.G., 2011. In-situ cosmogenic ${ }^{10}$ Be production rate at Lago Argentino, Patagonia: implications for late-glacial climate chronology. Earth Planet. Sci. Lett. 309, 21-32.

Kelly, M.A., Lowell, T.V., Applegate, P.J., Phillips, F.M., Schaefer, J.M., Smith, C.A., Kim, H., Leonard, K.C., Hudson, A.M., in press. A locally calibrated, late glacial ${ }^{10} \mathrm{Be}$ production rate from a low-latitude, high-altitude site in the Peruvian Andes. Quat. Geochronol.

Kong, P., Fink, D., Na, C.G., Huang, F.X., 2009a. Late Quaternary glaciation of the Tianshan, central Asia, using cosmogenic ${ }^{10}$ Be surface exposure dating. Quat. Res. 72, 229-233.

Kong, P., Na, C.G., Fink, D., Zhao, X.T., Xiao, W., 2009b. Moraine dam related to late Quaternary glaciation in the Yulong Mountains, southwest China, and impacts on the Jinsha River. Quat. Sci. Rev. 28, 3224-3235.

Koppes, M., Gillespie, A.R., Burke, R.M., Thompson, S.C., Stone, J., 2008. Late Quaternary glaciation in the Kyrgyz Tien Shan. Quat. Sci. Rev. 27, 846-866.

Kubik, P.W., Ivy-Ochs, S., 2004. A re-evaluation of the 0-10 ka ${ }^{10}$ Be production rate for exposure dating obtained from the Köfels (Austria) landslide. Nucl. Instrum. Methods Phys. Res. B 223-224, 618-622.

Kuhle, M., 2004. The high glacial (last ice age and LGM) ice cover in high and central Asia. In: Ehlers, J., Gibbard, P.L. (Eds.), Quaternary Glaciations - Extent and Chronology, Part III: South America, Asia, Africa, Australia, Antarctica. Elsevier, Amsterdam, pp. 175-199. 
Larsen, P.L., 1996. In-situ production rates of cosmogenic ${ }^{10} \mathrm{Be}$ and ${ }^{26} \mathrm{Al}$ over the past 21,500 years determined from the terminal moraine of the Laurentide ice sheet, north-central New Jersey. Ms thesis, University of Vermont.

Lasserre, C., Gaudemer, Y., Tapponnier, P., Mériaux, A.-S., Van der Woerd, J., Yuan, D.Y., Ryerson, F.J., Finkel, R.C., Caffee, M.W., 2002. Fast late Pleistocene slip rate on the Leng Long Ling segment of the Haiyuan fault, Qinghai, China. J. Geophys. Res. 107, B11 2276.

Lee, S.Y., Seong, Y.B., Owen, L.A., Murari, M.K., Lim, H.S., Yoon, H.I., Yoo, K.-C., 2014. Late Quaternary glaciation in the Nun-Kun massif, northwestern India. Boreas 43, 67-89.

Lehmkuhl, F., Owen, L.A., 2005. Late Quaternary glaciation of Tibet and the bordering mountains: a review. Boreas 34, 87-100.

Li, B.Y., Li, J.J., Cui, Z.J., Zheng, B.X., Zhang, Q.S., Wang, F.B., Zhou, S.Z., Shi, Z.H., Jiao, K.Q., Kang, J.C., 1991. Quaternary glacial distribution map of Qinghai-Xizang (Tibet) Plateau. Science Press, Beijing.

Li, Y.K., Liu, G.N., Kong, P., Harbor, J., Chen, Y.X., Caffee, M., 2011. Cosmogenic nuclide constraints on glacial chronology in the source area of the Urumqi River, Tian Shan, China. J. Quat. Sci. 26, 297-304.

Lifton, N., Sato, T., Dunai, T.J., 2014. Scaling in situ cosmogenic nuclide production rates using analytical approximations to atmospheric cosmic-ray fluxes. Earth Planet. Sci. Lett. 386, 149-160.

Liu, T.S., Zhang, X.S., Xiong, S.F., Qin, X.G., Yang, X.P., 2002. Glacial environments on the Tibetan Plateau and global cooling. Quat. Int. 97-98, 133-139.

Mark, B.G., Harrison, S.P., Spessa, A., New, M., Evans, D.J.A., Helmens, K.F., 2005. Tropical snowline changes at the last glacial maximum: a global assessment. Quat. Int. 138-139, 168-201.

Meierding, T.C., 1982. Late Pleistocene glacial equilibrium-line altitudes in the Colorado Front Range: a comparison of methods. Quat. Res. 18, 289-310.

Mériaux, A.-S., Ryerson, F.J., Tapponnier, P., Van der Woerd, J., Finkel, R.C., Xu, X.W., Xu, Z.Q., Caffee, M.W., 2004. Rapid slip along the central Altyn Tagh Fault: Morphochronologic evidence from Cherchen He and Sulamu Tagh. J. Geophys. Res. 109, B06401.

Miehe, G., Miehe, S., Bach, K., Kluge, J., Wesche, K., Yang, Y.P., Liu, J.Q., 2011. Ecological stability during the LGM and the mid-Holocene in the alpine steppes of Tibet? Quat. Res. 76, 243-252.

Murari, M.K., Owen, L.A., Dortch, J.M., Caffee, M.W., Dietsch, C., Fuchs, M., Haneberg, W.C., Sharma, M.C., Townsend-Small, A., 2014. Timing and climatic drivers for glaciation across monsoon-influenced regions of the Himalayan-Tibetan orogen. Quat. Sci. Rev. 88, 159-182.

Nishiizumi, K., Winterer, E.L., Kohl, C.P., Klein, J., Middleton, R., Lal, D., Arnold, J.R., 1989. Cosmic ray production rates of ${ }^{10} \mathrm{Be}$ and ${ }^{26} \mathrm{Al}$ in quartz from glacially polished rocks. J. Geophys. Res. 94, 17907-17915.

Nishiizumi, K., Imamura, M., Caffee, M.W., Southon, J.R., Finkel, R.C., McAninch, J., 2007. Absolute calibration of ${ }^{10}$ Be AMS standards. Nucl. Instrum. Methods Phys. Res. B 258, 403-413.

Owen, L.A., Benn, D.I., 2005. Equilibrium-line altitudes of the last glacial maximum for the Himalaya and Tibet: an assessment and evaluation of results. Quat. Int. 138-139, 55-78.

Owen, L.A., Dortch, J.M., 2014. Nature and timing of Quaternary glaciation in the Himalayan-Tibetan orogen. Quat. Sci. Rev. 88, 14-54.

Owen, L.A., Gualtieri, L., Finkel, R.C., Caffee, M.W., Benn, D.I., Sharma, M.C., 2001. Cosmogenic radionuclide dating of glacial landforms in the Lahul Himalaya, northern India: defining the timing of late Quaternary glaciations. J. Quat. Sci. 16, 555-563. 
Owen, L.A., Finkel, R.C., Caffee, M.W., Gualtieri, L., 2002. Timing of multiple late Quaternary glaciations in the Hunza Valley, Karakoram Mountains, northern Pakistan: defined by cosmogenic radionuclide dating of moraines. Geol. Soc. Am. Bull. 114, 593-604.

Owen, L.A., Finkel, R.C., Haizhou, M., Spencer, J.Q., Derbyshire, E., Barnard, P.L., Caffee, M.W., 2003a. Timing and style of Late Quaternary glaciation in northeastern Tibet. Geol. Soc. Am. Bull. 115, 1356-1364.

Owen, L.A., Ma, H.Z., Derbyshire, E., Spencer, J.Q., Barnard, P.L., Nian, Z.Y., Finkel, R.C., Caffee, M.W., 2003b. The timing and style of late Quaternary glaciation in the La Ji Mountains, NE Tibet: evidence for restricted glaciation during the latter part of the last glacial. Z. Geomorphol. Suppl. 130, 263-276.

Owen, L.A., Spencer, J.Q., Ma, H.Z., Barnard, P.L., Derbyshire, E., Finkel, R.C., Caffee, M.W., Nian, Z.Y., 2003c. Timing of Late Quaternary glaciation along the southwestern slopes of the Qilian Shan, Tibet. Boreas 32, $281-291$.

Owen, L.A., Finkel, R.C., Barnard, P.L., Ma, H.Z., Asahi, K., Caffee, M.W., Derbyshire, E., 2005. Climatic and topographic controls on the style and timing of late Quaternary glaciation throughout Tibet and the Himalaya defined by ${ }^{10}$ Be cosmogenic radionuclide surface exposure dating. Quat. Sci. Rev. 24, 1391-1411.

Owen, L.A., Caffee, M.W., Bovard, K.R., Finkel, R.C., Sharma, M.C., 2006a. Terrestrial cosmogenic nuclide surface exposure dating of the oldest glacial successions in the Himalayan orogen: Ladakh Range, northern India. Geol. Soc. Am. Bull. 118, 383-392.

Owen, L.A., Finkel, R.C., Ma, H.Z., Barnard, P.L., 2006b. Late Quaternary landscape evolution in the Kunlun Mountains and Qaidam basin, northern Tibet: a framework for examining the links between glaciation, lake level changes and alluvial fan formation. Quat. Int. 154-155, 73-86.

Owen, L.A., Caffee, M.W., Finkel, R.C., Seong, Y.B., 2008. Quaternary glaciation of the Himalayan-Tibetan orogen. J. Quat. Sci. 23, 513-531.

Owen, L.A., Robinson, R., Benn, D.I., Finkel, R.C., Davis, N.K., Yi, C.L., Putkonen, J., Li, D.W., Murray, A.S., 2009. Quaternary glaciation of Mount Everest. Quat. Sci. Rev. 28, 1412-1433.

Owen, L.A., Yi, C.L., Finkel, R.C., Davis, N.K., 2010. Quaternary glaciation of Gurla Mandhata (Naimon'anyi). Quat. Sci. Rev. 29, 1817-1830.

Owen L.A., Chen, J., Hedrick, K.A., Caffee, M.W., Robinson, A.C., Schoenbohm, L.M., Yuan, Z.D., Li, W.Q., Imrecke, D.B., Liu, J.F., 2012. Quaternary glaciation of the Tashkurgan Valley, southeast Pamir. Quat. Sci. Rev. 47, 56-72.

Phillips, W.M., Sloan, V.F., Shroder, J.F., Sharma, P., Clarke, M.L., Rendell, H.M., 2000. Asynchronous glaciation at Nanga Parbat, northwestern Himalaya mountains, Pakistan. Geology 28, 431-434.

Porter, S.C., 2001. Snowline depression in the tropics during the last glaciation. Quat. Sci. Rev. 20, 1067-1091.

Pratt-Sitaula, B., 2005. Glaciers, climate, and topography in the Nepalese Himalaya. PhD thesis, University of California, Santa Barbara.

Pratt-Sitaula, B., Burbank, D.W., Heimsath, A.M., Humphrey, N.F., Oskin, M., Putkonen, J., 2011. Topographic control of asynchronous glacial advances: a case study from Annapurna, Nepal. Geophys. Res. Lett. 38, L24502.

Putkonen, J., Swanson, T., 2003. Accuracy of cosmogenic ages for moraines. Quat. Res. 59, 255-261.

Putnam, A.W., Schaefer, J.M., Barrell, D.J.A., Vandergoes, M., Denton, G.H., Kaplan, M.R., Finkel, R.C., Schwartz, R., Goehring, B.M., Kelley, S.E., 2010. In situ cosmogenic ${ }^{10}$ Be production-rate calibration from the Southern Alps, New Zealand. Quat. Geochronol. 5, 392-409.

Reimer, P.J., Bard, E., Bayliss, A., Beck, J.W., Blackwell, P.G., Bronk Ramsey, C., Buck, C.E., Cheng, H., Edwards, R.L., Friedrich, M., Grootes, P.M., Guilderson, T.P., Haflidason, H., Hajdas, I., Hatté, C., Heaton, T.J., Hoffmann, D.L., Hogg, A.G., Hughen, K.A., Kaiser, K.F., Kromer, B., Manning, S.W., Niu, M., Reimer, R.W., Richards, D.A., Scott, 
E.M., Southon, J.R., Staff, R.A., Turney, C.S.M., van der Plicht, J., 2013. IntCal13 and Marine13 radiocarbon age calibration curves 0-50,000 years cal BP. Radiocarb. 55, 1869-1887.

Röhringer, I., Zech, R., Abramowski, U., Sosin, P., Aldahan, A., Kubik, P.W., Zöller, L., Zech, W., 2012. The late Pleistocene glaciation in the Bogchigir Valleys (Pamir, Tajikistan) based on ${ }^{10}$ Be surface exposure dating. Quat. Res. 78, 590-597.

Rupper, S., Roe, G., 2008. Glacier changes and regional climate: a mass and energy balance approach. J. Clim. 21, 5384-5401.

Schaefer, J.M., Oberholzer, P., Zhao, Z.Z., Ivy-Ochs, S.4, Wieler, R., Baur, H., Kubik, P.W., Schlüchter, C., 2008. Cosmogenic beryllium-10 and neon-21 dating of late Pleistocene glaciations in Nyalam, monsoonal Himalayas. Quat. Sci. Rev. 27, 295-311.

Schäfer, J.M., 2000. Reconstruction of landscape evolution and continental paleoglaciations using in-situ cosmogenic nuclides: examples from Antarctica and the Tibetan Plateau. PhD thesis, ETH Zürich.

Schäfer, J.M., Tschudi, S., Zhao, Z.Z., Wu, X.H., Ivy-Ochs, S., Wieler, R., Baur,H., Kubik, P.W., Schlüchter, C., 2002. The limited infuence of glaciations in Tibet on global climate over the past $170000 \mathrm{yr}$. Earth Planet. Sci. Lett. 194, 287-297.

Scherler, D., Bookhagen, B., Strecker, M.R., von Blanckenburg, F., Rood, D., 2010. Timing and extent of late Quaternary glaciation in the western Himalaya constrained by ${ }^{10}$ Be moraine dating in Garhwal, India. Quat. Sci. Rev. 29, 815-831.

Scherler, D., Munack, H., Mey, J., Eugster, P., Wittmann, H., Codilean, A.T., Kubik, P., Strecker, M.R., in press. Ice dams, outburst floods, and glacial incision at the western margin of the Tibetan Plateau: A >100 k.y. chronology from the Shyok Valley, Karakoram. Geol. Soc. Am. Bull.

Schmidt, J., Opgenoorth, L., Martens, J., Miehe, G., 2011. Neoendemic ground beetles and private tree haplotypes: two independent proxies attest a moderate last glacial maximum summer temperature depression of $3-4{ }^{\circ} \mathrm{C}$ for the southern Tibetan Plateau. Quat. Sci. Rev. 30, 1918-1925.

Seong, Y.B., Owen, L.A., Bishop, M.P., Bush, A., Clendon, P., Copland, L., Finkel, R., Kamp, U., Shroder, J.F., 2007. Quaternary glacial history of the central Karakoram. Quat. Sci. Rev. 26, 3384-3405.

Seong, Y.B., Owen, L.A., Yi, C.L., Finkel, R.C., 2009. Quaternary glaciation of Muztag Ata and Kongur Shan: evidence for glacier response to rapid climate changes throughout the late glacial and Holocene in westernmost Tibet. Geol. Soc. Am. Bull. 121, 348-365.

Shi, Y.F., 2002. Characteristics of late Quaternary monsoonal glaciation on the Tibetan Plateau and in east Asia. Quat. Int. 97-98, 79-91.

Stone, J.O., Ballantyne, C.K., Fifield, L.K., 1998. Exposure dating and validation of periglacial weathering limits, northwest Scotland. Geology 26, 587-590.

Strasky, S., Graf, A.A., Zhao, Z.Z., Kubik, P.W., Baur, H., Schlüchter, C., Wieler, R., 2009. Late glacial ice advances in southeast Tibet. J. Asian Earth Sci. 34, 458-465.

Thompson, L.G., Yao, T., Davis, M.E., Henderson, K.A., Mosley-Thompson, E., Lin, P.-N., Beer, J., Synal, H.-A., ColeDai, J., Bolzan, J.F., 1997. Tropical climate instability: the last glacial cycle from a Qinghai-Tibetan ice core. Science 276, 1821-1825.

Tschudi, S., Schäfer, J.M., Zhao, Z.Z., Wu, X.H., Ivy-Ochs, S., Kubik, P.W., Schlüchter, C., 2003. Glacial advances in Tibet during the Younger Dryas? Evidence from cosmogenic ${ }^{10} \mathrm{Be},{ }^{26} \mathrm{Al}$, and ${ }^{21} \mathrm{Ne}$. J. Asian Earth Sci. 22, 301-306.

Wang, J., Yiou, F., Raisbeck, G., Xu, X.B., 2003. Reconstructing the history of drift boulders' movement by using the autochthonous cosmogenic isotope ${ }^{10} \mathrm{Be}$. Acta Geol. Sin. 77, 407-413. [In Chinese, English abstract] 
Wang, J., Raisbeck, G., Xu, X.B., Yiou, F., Bai, S.B., 2006. In situ cosmogenic ${ }^{10}$ Be dating of the Quaternary glaciations in the southern Shaluli Mountain on the southeastern Tibetan Plateau. Sci. China Ser. D: Earth Sci. 49, 12911298.

Wang, J., Kassab, C., Harbor, J.M., Caffee, M.W., Cui, H., Zhang, G.L., 2013. Cosmogenic nuclide constraints on late Quaternary glacial chronology on the Dalijia Shan, northeastern Tibetan Plateau. Quat. Res. 79, 439-451.

Xu, X.K., Hu, G., Qiao, B.J., 2013. Last glacial maximum climate based on cosmogenic ${ }^{10} \mathrm{Be}$ exposure ages and glacier modeling for the head of Tashkurgan Valley, northwest Tibetan Plateau. Quat. Sci. Rev. 80, 91-101.

Yao, T.D., Liu, X.D., Wang, N.L., Shi, Y.F., 2000. Amplitude of climatic changes in Qinghai-Tibetan Plateau. Chin. Sci. Bull. 45, 1236-1243.

Young, N.E., Schaefer, J.M., Briner, J.P., Goehring, B.M., 2013. A ${ }^{10}$ Be production-rate calibration for the Arctic. J. Quat. Sci. 28, 515-526.

Zech, R., 2012. A late Pleistocene glacial chronology from the Kitschi-Kurumdu Valley, Tien Shan (Kyrgyzstan), based on ${ }^{10} \mathrm{Be}$ surface exposure dating. Quat. Res. 77, 281-288.

Zech, R., Abramowski, U., Glaser, B., Sosin, P., Kubik, P.W., Zech, W., 2005. Late Quaternary glacial and climate history of the Pamir Mountains derived from cosmogenic ${ }^{10}$ Be exposure ages. Quat. Res. 64, 212-220.

Zech, R., Zech, M., Kubik, P.W., Kharki, K., Zech, W., 2009. Deglaciation and landscape history around Annapurna, Nepal, based on ${ }^{10}$ Be surface exposure dating. Quat. Sci. Rev. 28, 1106-1118.

Zech, R., Röhringer, I., Sosin, P., Kabgov, H., Merchel, S., Akhmadaliev, S., Zech, W., 2013. Late Pleistocene glaciations in the Gissar Range, Tajikistan, based on ${ }^{10} \mathrm{Be}$ surface exposure dating. Palaeogeogr. Palaeoclimatol. Palaeoecol. 369, 253-261.

Zheng, Y.Q., Yu, G., Wang, S.M., Xue, B., Zhuo, D.Q., Zeng, X.M., Liu, H.Q., 2004. Simulation of paleoclimate over east Asia at 6 ka BP and 21 ka BP by a regional climate model. Clim. Dyn. 23, 513-529.

Zhou, S.Z., Xu, L.B., Colgan, P.M., Mickelson, D.M., Wang, X.L., Wang, J., Zhong, W., 2007. Cosmogenic ${ }^{10}$ Be dating of Guxiang and Baiyu glaciations. Chin. Sci. Bull. 52, 1387-1393. 